\title{
From on-farm solid-set sprinkler irrigation design to collective irrigation network design in windy areas
}

by

\author{
Zapata, N. 1, Playán, E. 2, Martínez-Cob, A. ${ }^{2}$,
}

Sánchez, I. ${ }^{1}$, Faci, J. M. ${ }^{1}$, Lecina, S. ${ }^{3}$

\section{$\underline{\text { Abstract }}$}

In this paper, a contribution to the design of collective pressurized irrigation networks in solid-set sprinkler irrigated windy areas is presented. The methodology is based on guaranteeing minimum on-farm performance, using a historical hourly wind speed database and a ballistic solid-set irrigation simulation model. The proposed method was applied to the Montesnegros Irrigation District (central Ebro basin, Spain). The district irrigates an area of 3,493 ha using an on-demand schedule. The average wind speed in the area is $2,8 \mathrm{~m} \mathrm{~s}^{-1}$. An analysis of district water records showed that farmers often reduce water demand when the wind speed is high, but their irrigation

$1(\varangle)$ Dept. of Soils and Irrigation, Centro de Investigación y Tecnología Agroalimentaria (CITA-DGA), Diputación General de Aragón. Apdo. 727, 50080 Zaragoza, Spain. Tel: +34 976716 324. FAX: + 34976716 335. Email: vzapata@aragon.es 2 Dept. Genetics and Plant Production, Estación Experimental de Aula Dei (EEAD), CSIC, Apdo. 202, 50080 Zaragoza, Spain.

${ }^{3}$ Ager-Ingenieros. C/Mayor 53, 2º. 50001. Zaragoza, Spain. 
1 decision making is limited by the capacity of the irrigation network and by the

2 unpredictable character of local winds. Simulations were performed for eleven

3 irrigation seasons, two triangular sprinkler spacings (18x18 and 18x15 m), and two

4 sprinkler models. The percentage of monthly suitable time for irrigation was

5 determined for four management strategies. The first one was based on a wind speed

6 threshold $\left(3 \mathrm{~m} \mathrm{~s}^{-1}\right)$, while the other three were based on three levels (standard, relaxed

7 and restrictive) of two irrigation performance parameters: the Christiansen Uniformity

8 Coefficient $(C U)$ and the Wind Drift and Evaporation Losses (WDEL). The thresholds

9 for the standard strategy were $C U \geq 84 \%$ and $W D E L \leq 20 \%$. The suitable time for the

10 first strategy (56\%) was always lower than for the standard and the relaxed strategies

11 (with respective average values of 75 and $86 \%$ ), and higher than for the restrictive

12 strategy (30\%). In order to design the collective network, the hydrant operating time

13 was equalled to the suitable time for irrigation. The differences in the cost of the

14 collective network plus the on-farm equipment were particularly relevant between the restrictive strategy and the other three. Differences in suitable operating time were clear between sprinkler spacings, and less evident between sprinkler models. The

17 application of the proposed methodology may be limited by the availability of

18 historical wind speed records and $\mathrm{CU}$ estimates for different combinations of sprinkler models, sprinkler spacings and wind speed. 


\section{Introduction}

3 subject of a number of research works, due to the relevance of its economic,

4 environmental and social aspects (Alperovits and Shamir, 1977; Goulter and Morgan,

5 1985; Savic and Walters, 1997; Lansey et al., 1989). The design objective is to obtain

6 networks which are flexible enough to permit efficient on-farm irrigation, leading to

7 high crop yields at moderate investment and operational costs.

Among the different types of irrigation delivery schemes, the on-demand scheme offers the greatest potential (Lamaddalena and Sagardoy, 2000). This scheme provides farmers with great flexibility, allowing them to adjust water application to crop water requirements. On-demand design of collective irrigation networks must meet the discharge requirements during the peak period. A minimum hydrant pressure must also be guaranteed to ensure appropriate on-farm performance.

One of the main design problems of large, collective water supply and distribution systems lies in the estimation of hydrant discharge during the peak period. Since the probability of having all the network hydrants simultaneously open is very low, probabilistic criteria have been widely used to determine flow rates at the design stage (Clément, 1966; Clément and Galand, 1979; Lamaddalena and Sagardoy, 2000). This classical approach uses only one flow regime (corresponding to the peak period) to design the network. One of the key parameters of this approach is the hydrant available operating time (as a percent of the total time)._The uncertainty of water demand has been widely researched in the context of urban water networks (Lansey et al., 1989; Lansey, 2000; Babayan et al., 2004; Farmani et al., 2005). 
Several authors have argued that farmers' application criteria and preferences

2 are not included in the probabilistic approach (D`Urso et al., 1995; Pulido-Calvo et al,

3 2003), while these issues have a relevant effect on network performance. Pulido-Calvo

4 et al. (2003) presented a method in which different working probabilities were assigned

5 to each hydrant depending on energy costs (these costs may vary during the day).

6 Monserrat et al. (2004), presented an analysis of the Clèment's first formula, comparing

7 it to real data from two irrigation networks. These authors found that differences

8 between the demand simulated by Clément and the real demand were smaller than

$9 \quad 9.4 \%$ for a wide range of operating conditions. Planells et al. (2005) presented a process

10 of daily random generation of demand curves applied to the problem of pumping

11 requirements in on-demand irrigation networks.

In windy solid-set sprinkler-irrigated areas, the farmers' application criteria greatly influence the working probability of the hydrants. Farmers frequently avoid irrigation under windy conditions because of higher wind drift and evaporation losses (Frost and Schwalen, 1955; Tarjuelo et al., 2000; Playán et al., 2005) and lower irrigation uniformity (Dechmi et al., 2003b; Dechmi et al., 2004). Neglecting wind-induced farmers' criteria could lead to a severe underestimation of the peak flow and therefore of the system capacity. As a consequence, wind-wise, efficient irrigation management would be greatly difficulted. Although wind speed is the most important meteorological variable affecting sprinkler irrigation performance (Playán el al., 2005), its effect is conditioned by other technical variables such as sprinkler spacing, operating pressure, nozzle diameter and sprinkler type (Keller and Bliesner, 1990, Tarjuelo et al., 1992).

According to Vories et al. (1987), wind effects should be considered when designing a solid-set sprinkler irrigation system in an area subjected to nearly constant 
1 wind speed and direction. While in some areas the wind direction shows a clear

2 pattern, Dechmi et al. (2003b) reported that wind direction and, particularly, wind

3 speed are often subjected to a large variability within a given day and among days.

4 These same authors concluded that this time variability poses a serious limitation to

5 the adequate design of sprinkler irrigation systems and makes water management a

6 difficult task.

8 been developed in the last decades (Fukui et al, 1980; Carrión el al., 2001; Montero et

9 al., 2001; Dechmi et al., 2004; Lorenzini, 2004). Since an intense process of calibration

Solid-set sprinkler irrigation simulation models based on ballistic theory have and validation is required for each combination of sprinkler, nozzle and operation conditions, only a few applications of ballistic models have been reported (Montero et al, 2001; Playán et al, 200Xb). Modelling techniques permit to reproduce a given onfarm irrigation event subjected to different technical and meteorological conditions. As a consequence, simulation models can be used to improve on farm and network irrigation design in windy areas.

This paper presents a contribution to the design of collective pressurized irrigation networks in solid-set sprinkler irrigated windy areas. A methodology to characterise the combined effects of wind speed and on-farm irrigation design variables is presented. This methodology was applied to determine the suitable time for irrigation in a windy district, using a meteorological data series of eleven years in combination with a ballistic simulation model. The methodology is based on adopting minimum thresholds for irrigation performance parameters and establishing the available operating time as the time when those thresholds are exceeded. 


\section{$1 \quad$ Materials and Methods}

\section{Solid-set sprinkler Irrigation District description}

The Montesnegros Irrigation District is located near Bujaraloz (Aragón region,

4 central Ebro valley, Spain). The district, with an irrigated area of 3,493 ha, is solid-set

5 sprinkler irrigated with an on-demand schedule. The irrigation network has 405

6 hydrants. The total network discharge is recorded at the pumping station SCADA

7 every five minutes. The maximum network capacity is $241,920 \mathrm{~m}^{3} \mathrm{~d}^{-1}$. The district area

8 is classified as windy (Puicercús et al., 1994), since the average daily wind speed (2.8 $\mathrm{m}$ $\mathrm{s}^{-1}$ ) exceeds $2 \mathrm{~m}_{-} \mathrm{s}^{-1}$. The district shows a clear pattern for wind direction, particularly

10 when the average daily speed is exceeded. Water allocation data for the 2001 and 2002

11 irrigation seasons were available at the Irrigation District database. The Ador software

12 (Playán et al., 200Xa) was used at the district office to store and process water meter

13 readings and the crops associated to each plot, among other variables.

\section{Meteorological data}

Meteorological data were recorded using an automatic meteorological station located within the Irrigation District area $\left(41^{\circ} 31^{\prime} 25^{\prime \prime} \mathrm{N}, 0^{\circ} 10^{\prime} 24^{\prime \prime} \mathrm{W}\right)$. Hourly averages of wind speed $\left(U, \mathrm{~m} \mathrm{~s}^{-1}\right)$, air temperature $\left(T,{ }^{\circ} \mathrm{C}\right)$, and relative humidity $(R H, \%)$ were recorded for 11 years (from 1993 to 2003). Only the hourly data belonging to the irrigation season (April to September) were analysed. Reference crop evapotranspiration was determined at the study area for the 2001 and 2002 irrigation seasons using the Hargreaves equation (Hargreaves and Samani, 1985). Local crop

Eliminado: A data set of eleven years ranging from

Eliminado: , with a recording frequency of 30 minutes, was used. The recorded meteorological variables were wind speed $\left(U, \mathrm{~m} \mathrm{~s}^{-1}\right)$, air temperature $\left(T,{ }^{\circ} \mathrm{C}\right)$, and relative humidity $(\mathrm{RH}, \%)$. $\mathrm{O}$ coefficients (Tejero, 2003) were combined with reference crop evapotranspiration and effective precipitation to estimate crop water requirements. 


\section{Description of the solid-set simulation model}

A sprinkler irrigation simulation model based on ballistic theory was used to simulate irrigation events in the Montesnegros Irrigation District. In ballistic models, a sprinkler is simulated as a device emitting drops of different diameters. It is assumed that drops are formed at the sprinkler nozzle, and travel independently until reaching the soil surface (or the crop canopy). In the absence of wind, and for a given sprinkler configuration, the horizontal distance between the drop landing point and the sprinkler nozzle is a function of the drop diameter. Ballistic theory is used to determine the trajectory of each drop diameter subjected to an initial velocity vector and a wind vector. The action of gravity (acting in the vertical direction) and the resistance force (opposite to the drop trajectory) complete the analysis of forces acting on the water drop. General details about the construction and testing of ballistic models can be found in Fukui et al. (1980) and Carrión et al. (2001).

The model used in this work was presented by Playán et al. (200Xb) and has been calibrated and validated for two sprinkler types: "VYR-70", manufactured by VYRSA (Briviesca, Burgos, Spain) and "RC-130H" manufactured by Riegos Costa S.L. (Lleida, Spain) (the citation of commercial trademarks does not imply endorsement). Both sprinkler models are frequently installed in the central Ebro valley of Spain. Two principal nozzle diameters ( 4.0 and $4.4 \mathrm{~mm}$ ) plus an auxiliary $2.4 \mathrm{~mm}$ nozzle were used in the calibration and validation process, operating in a wide range of pressures (200$400 \mathrm{kPa}$ ) and wind speeds.

\section{Model application}

The model requires a combination of meteorological and operational conditions in order to simulate an irrigation event. Meteorological conditions were derived from 
1 the eleven seasonal data sets. The total number of hours in each data set represents the

2 potential available time for irrigation. Two sprinkler spacings were simulated: a

3 sprinklers within the same irrigation line (T18x18), and a triangular spacing with a
Six intervals were used to characterize wind speed in the study area (Dechmi et al., 2004). The frequency corresponding to each interval was calculated on a monthly basis for the eleven irrigation seasons. Daily district water delivery for the seasons 2001 and 2002 was contrasted with wind speed in order to assess the current irrigation management practices. Relationships between water delivery and different wind conditions were established. Monthly day and night water deliveries were also characterised for the two seasons. Water delivery from 7:00 GMT to 19:00 GMT was considered as day time delivery. The remaining daily water allocation was considered as night time delivery

The suitable time for irrigation (\%) was determined following four irrigation management strategies. The first strategy was established taking into consideration the
Eliminado: eters

Eliminado: eters

Eliminado: eters

Eliminado: eters
Eliminado:

Eliminado: 
1 wind speed limit for sprinkler irrigation operation reported by Tarjuelo et al. (1992).

2 These authors proposed a threshold of $3 \mathrm{~m} \mathrm{~s}^{-1}$ for irrigation operation in a triangular 18

3 $\mathrm{m} \times 18 \mathrm{~m}$ sprinkler spacing. For this first irrigation management strategy, the hours

4 with a wind speed exceeding $3 \mathrm{~m} \mathrm{~s}^{-1}$ were classified as non suitable for irrigation. The

5 three remaining strategies were established taking into account two irrigation

6 performance parameters: the Christiansen Uniformity Coefficient (CU) (Burt et al.,

7 1997) and the Wind Drift and Evaporation Losses (WDEL), expressed as a percentage

8 of the emitted discharge. The following equation, developed for day and night

9 operation (Playán et al., 2005), was implemented in the model to estimate WDEL from

10 meteorological data:

The second management strategy was based on threshold values for $C U$ and WDEL: irrigation can only be performed if $C U \geq 84 \%$ and $W D E L \leq 20 \%$. The threshold value of CU was selected following the recommendation by Keller and Bliesner (1990). The threshold value of WDEL was taken from Martinez-Cob et al. (2005), who presented values of WDEL averaging about $20 \%$ in local windy areas. This management strategy was considered as "standard", and the remaining two strategies include threshold values deviating from the standard. The third management strategy, denoted "restrictive", was characterised by $C U \geq 90 \%$ and WDEL $\leq 15 \%$. This criterion could be adequate in irrigation districts with high water costs and/or high crop values and/or water scarcity. The fourth management strategy, denoted as "relaxed" was characterised by $C U \geq 80 \%$ and $W D E L \leq 25 \%$. 
3 the different on-farm technical configurations (two sprinklers $x$ two spacings) were

4 also established. The four strategies and the different on-farm configurations were also 5 compared in economic terms for the conditions of the central Ebro Valley. The 6 comparison was only established in terms of the irrigation investment costs, 7 considering the collective network and the on-farm equipment. Investment was expressed in terms of total cost $\left(€ \mathrm{ha}^{-1}\right)$ and yearly payback cost $\left(€ \mathrm{ha}^{-1} \mathrm{yr}^{-1}\right)$

The four abovementioned management strategies were compared in terms of suitable time for irrigation (average and 20\% return probability). Comparisons between

The construction cost $\left(€ \mathrm{ha}^{-1}\right)$ of a new irrigation network designed for different values of hydrant operating time (determined in this paper as the suitable time for irrigation) was estimated for the conditions of the Callén Irrigation District. This district is located in the vicinity of the Montesnegros district, and its pressurized network is currently being designed as part of an irrigation modernization project. Having similar extension, meteorology and irrigation layout, the network construction costs $\left(€\right.$ ha $\left.^{-1}\right)$ of both districts are expected to be similar. The investment cost of on-farm irrigation equipment was estimated for the T18x18 and T18x15 solid-set spacings. The cost of the solid-set did not depend on the choice of sprinkler model, since their prices are similar. The yearly irrigation investment payback was determined considering a lifespan of 50 years, and following the current financing conditions set-out by the local banks.

Finally, the time distribution of the non suitable hours for irrigation was analysed. The monthly number of groups of $1 / 3,1,2,3$ and 4 days non suitable for irrigation was established for the four management strategies and for the four on-farm
Eliminado:

Eliminado: 
1 technical configurations. Average, maximum, minimum and $20 \%$ return probability

2 statistics were determined for each case. 


\section{Results and discussion}

Field crops are grown in the wide majority of the district area, with corn and alfalfa being the most frequent. For the two analysed irrigation seasons, a decrease in percent corn area was observed: from $64 \%$ to $55 \%$. An increase of the same order was observed for alfalfa: from $24 \%$ to $32 \%$. Horticultural crops follow in this ranking, and are characterised by a slight increment in time: from $4 \%$ to $6 \%$. The area devoted to winter cereals (4\%) and fallow (4\%) remained constant during the two seasons.

Figure 1 presents the daily net irrigation requirements and water deliveries for the Montesnegros Irrigation District during the 2001 and 2002 seasons. Adequate agreement between both variables was generally observed. Figure 1 shows that the irrigation network operated at maximum capacity $\left(241,920 \mathrm{~m}^{3} \mathrm{~d}^{-1}\right)$, and even slightly beyond this limit, throughout the peak period of crop irrigation requirements, around July, A limited network capacity resulted in relatively stable maximum values of daily water deliveries during the peak of the season.

\section{Meteorological data}

The characterization of wind speed at the study area for the eleven year data set is presented in Figure 2. April is the month most affected by high wind speeds (in $45 \%$ of the time the wind speed exceeds $3 \mathrm{~m} \mathrm{~s}^{-1}$ ), followed by July (in 38\% of the time the wind speed exceeds $3 \mathrm{~m} \mathrm{~s}^{-1}$ ). April is the windiest month, while July shows the highest monthly crop water requirements (Figure 1 ).

Figure 3 presents the evolution of water delivery and wind speed for April and July, and for the two analysed irrigation seasons (2001 and 2002). Wind speed peaks generally result in reduced water delivery (e.g., the two windy periods of mid July
Eliminado: The $\mathrm{f}$

Eliminado: , the irrigation network operated at maximum capacity $\left(241,920 \mathrm{~m}^{3} \mathrm{~d}^{-1}\right)$, and even slightly beyond this limit 
1 2001). A regression analysis revealed that wind speed can explain $8,2 \%$ and $14,1 \%$ of the

2 variability in water delivery in April and July, respectively. The difference between

3 both months is partly due to the fact that crop water requirements increase during the

4 month of April, and remain fairly stable during July (Figure 1). Although both 5 regressions are highly significant $(\mathrm{P}<0.001$ in both cases), the predictive capacity of 6 the resulting models is very low, suggesting that wind speed can only explain the 7 variability of water delivery under certain circumstances. Further to this analysis, Table

81 presents the water deliveries $\left(\mathrm{L} \mathrm{s}^{-1}\right)$ for April and July, for the two seasons. Average

$9 \quad$ values are presented for periods over and below wind speed thresholds of 3.0 and 4.5 $\mathrm{m} \mathrm{s}^{-1}$. Day and night water deliveries are also presented in Table 1 . In April of both irrigation seasons, the water delivery pattern showed a clear response to wind speed.

The April ratio between average daily water delivery over and below $3.0 \mathrm{~m} \mathrm{~s}^{-1}$ was computed as 0.67 and 0.62 for 2001 and 2002, respectively. In July, this ratio adopted values of 0.87 and 0.95 for 2001 and 2002, respectively. Similar results were found for the $4.5 \mathrm{~m} \mathrm{~s}^{-1}$ threshold, although farmers were more effective avoiding wind speeds over $4.5 \mathrm{~m} \mathrm{~s}^{-1}$ than they were for $3.0 \mathrm{~m} \mathrm{~s}^{-1}$.

Farmers' selection of low winds was not particularly effective in April, when the network capacity permits to select the adequate irrigation timing. In July, farmers tended to avoid large winds, but seemed to be constrained by the network capacity. In many areas of the world, wind speeds are much lower during the night time than during the day time. As a consequence, night irrigation is frequently advised to optimise irrigation efficiency. In the Montesnegros District, day and night water delivery are very similar in April and July. The day/night delivery ratio was computed as 0.93 for both April and July, for 2001, and as 0.87 and 0.93 for April and July, respectively, for 2002. These small differences are supported by intense night winds in the area, with average day/night wind speed ratios of 1.25 and 1.18 for April and July, 
1 respectively. In the absence of a clear day/night wind pattern, attaining high irrigation

2 efficiency will depend more on reacting to the actual wind conditions than on applying

3 preset irrigation rules.

The Montesnegros District water delivery pattern seems to unveil relevant

5 network capacity restrictions. As a consequence, farmers could not successfully deal

6 with high wind speeds and high crop water requirements at the same time, and saw

7 themselves forced to irrigate under unsuitable environmental conditions. The fact that

8 in April farmers only moderately succeed to select adequate winds could be due to the

9 absenteeism promoted by the generalised use of on-farm irrigation programmers. In

10 July, when crop water requirements reach peak values and the network operates at full

11 capacity, farmers often use a fixed irrigation schedule in their programmers, regardless

12 of wind speed.

The relationship between yield and irrigation uniformity in solid-set sprinkler irrigation has been described in the literature (Li, 1998; Dechmi et al., 2004). In the case of corn, this relationship is particularly significant during the month of July. The combination of peak water requirements and drought sensitivity makes this month a critical period for the analysis of the suitable time for irrigation in the study area.

\section{Suitable time for irrigation}

Table 2 presents the results for the first irrigation strategy $\left(U<3 \mathrm{~m} \mathrm{~s}^{-1}\right)$, which does not depend on farm design variables. The monthly percentage of suitable hours is presented for each year and month of the irrigation season. Results are also presented for the average year and for the $20 \%$ return probability. Differences between years are relevant, with coefficients of variation of $20 \%$ for April and $14 \%$ for July. When it comes to comparing design oriented strategies, the season with a $20 \%$ return probability is more adequate than the average season. Following this criterion, April is 
1 the most restrictive month in terms of suitable hours (48\%). As previously discussed,

2 July is the most restrictive in terms of crop water requirements, and is characterised by

3 a percentage of suitable hours of $56 \%$. For the whole irrigation season, $62 \%$ of the

4 irrigation time is suitable for sprinkler irrigation (20\% return probability).

Table 3 presents the monthly percentage of suitable hours for the standard management strategy. Results are presented for the two sprinkler types (VYR-70 and $\mathrm{RC}-130 \mathrm{H})$ and for the two triangular sprinkler spacings (T18x18 and T18x15). Overall, April is the most restrictive month, while August is the least restrictive. There is a clear difference on suitable time between sprinkler spacings, with the ample spacing resulting in lower suitable time than the narrow spacing $(19 \%$ difference in seasonal terms for the $20 \%$ return probability). Comparing sprinkler types, in the ample spacing VYR-70 performs better than RC-130H. In the narrow spacing the performance of both sprinklers is similar, with VYR-70 showing a small advantage. Focusing on July, the highest suitable time is obtained with a VYR-70 sprinkler installed in a T18x15 spacing. This configuration is characterised by $85 \%$ of suitable hours (with a $20 \%$ return probability). The opposite choice for July (RC-130H and T18x18) is characterised by $63 \%$ of suitable hours. In this particular case, the choice of sprinkler model and a small difference in sprinkler spacing results in $22 \%$ difference in suitable time. Such a difference can play a major role in water use and/or crop yield.

The percentage of monthly suitable hours for irrigation for the restrictive strategy is presented in Table 4. Restrictions on irrigation performance parameters drastically decrease the suitable time for irrigation. For the $20 \%$ return probability, the percentage of suitable hours in July ranges from 22 to $35 \%$, depending on the irrigation hardware. Between months, April is always the most restrictive. The difference between sprinkler spacings is not as clear as in the standard strategy. For VYR-70 the 
1 narrow spacing (T18x15) performs better than the ample spacing (T18x18), with a

2 difference of $4 \%$ on July, and of $2 \%$ in seasonal terms. In the case of $\mathrm{RC}-130 \mathrm{H}$ the

3 results do not follow the usual trend, and the ample spacing outperforms the narrow

4 spacing by a seasonal difference of $11 \%$. The difference between sprinkler types is not

5 clear for the ample spacing, while for the narrow spacing VYR-70 performs better than

6
Table 5 presents the monthly percentage of suitable hours for irrigation for the relaxed strategy. The decrease on the irrigation performance thresholds results in a general increase of the suitable irrigation time, as compared with the two abovementioned strategies. The choice of sprinkler spacing greatly affects the time availability, with the narrow spacing presenting $21 \%$ more suitable time than the ample spacing (20\% return probability). The differences between sprinkler models are larger for the ample spacing than for the narrow spacing, with VYR-70 showing better performance than $\mathrm{RC}-130 \mathrm{H}_{\text {, }}$

Figure 4 presents the percentage of suitable hours for irrigation in July for the four analysed strategies. For the strategies based on simulation results, Figure 4 presents data for the four analysed combinations of sprinkler models and spacings. The suitable time for irrigation for the first strategy (56\%) is comparable to the standard strategy for the RC-130H sprinkler model at a T18x18 spacing (63\%). The other three on-farm hardware combinations present larger suitable time percentages. The suitable time for the first strategy $\left(U<3 \mathrm{~m} \mathrm{~s}^{-1}\right)$ is always lower than for the standard and the relaxed strategies (with respective average values of 75 and $86 \%$ ), and higher than for the restrictive strategy (average suitable time of 30\%). The difference between the standard and the relaxed strategies is moderate $(11 \%)$, while the difference
Eliminado:

Eliminado: 
1 between the standard and the restrictive strategies is very important (45\%). Table 6

2 presents the average values for $U, C U$ and $W D E L$ for each combination of management

3 strategy and on-farm equipment. In the case of the first management strategy $\left(U_{k}<3_{k} \mathrm{~m}\right.$

$4 \mathrm{~s}^{-1}$ ), different values of $\mathrm{CU}$ are presented for each on-farm configuration, as obtained

5 with the simulation model. Differences between strategies for average $U, C U$ and

6 WDEL are not particularly important, since the thresholds of all strategies were

7 exceeded in a large part of the total number of irrigation hours.

The standard strategy reveals relevant differences between sprinkler spacings, and moderate differences between sprinkler types. On the average, the T18x15 spacing permits to irrigate in $83 \%$ of the time, while the T18x18 spacing reduces the suitable time to $67 \%$. This $16 \%$ difference can be very relevant in terms of irrigation design and management. It is worth noting that the difference in sprinkler irrigated area between both spacings also amounts to $16 \%$. Regarding sprinkler models, they show a moderate difference of $6 \%$, with absolute values of 78 and $72 \%$ for VYR-70 and RC- $130 \mathrm{H}$, respectively.

A low suitable time for irrigation implies that crop water requirements must be fulfilled in a short period of time. As a consequence, the capacity of the irrigation network (pipeline diameters and hydrant capacities) must be enlarged, resulting in increased investment costs. Irrigation Districts combining meteorological constrains (high wind speeds), high crop water requirements and low water productivity (derived from low income crops) will not be able to afford the high performance provided by the restrictive management strategy. Montesnegros and a number of other Irrigation Districts in the central Ebro Valley of Spain combine all the abovementioned constrains. 
The analysis above reveals that the choice of a management strategy is linked to

2 the choice on-farm irrigation hardware (i. e., the sprinkler model and spacing). The

3 suitable time for irrigation (the hydrant operating time) is one of the main input

4 variables in collective irrigation network design. In parallel, all these decisions

5 influence crop agronomy, yield and water use. A complete economic analysis is

6 required to determine the most convenient management strategy in each particular

7 case. The analysis used in this paper does not permit to draw conclusions on crop yield

8 differences among strategies, thus restricting the possibility of applying a complete

9 economic analysis. In order to illustrate the economic implications of the management

10 strategies, one relevant economic variable will be discussed: the construction cost of

11 the irrigation district.

\section{Construction costs: irrigation network and on-farm equipment}

An approximation to the construction cost of an irrigation district in the study area is presented in Table 6 for each management strategy and on-farm hardware configuration. Differences in network investment resulted important, particularly between the restrictive strategy (averaging 7,444€ ha-1) and the other three (averaging 5,145, 4,675 and 4,456 € ha-1 for the $\mathrm{U}<3 \mathrm{~m} \mathrm{~s}^{-1}$, standard and relaxed strategies, respectively). The network investment cost was inversely proportional to the operating time. When all investment costs were considered, the strategies could be ranked as: relaxed $<$ standard $<\left(\mathrm{U}<3 \mathrm{~m} \mathrm{~s}^{-1}\right)<$ restrictive (with average values of 8,003, 8,222, 8,692 and $10,990 €$ ha-1 $^{-1}$ respectively). The analysis of the yearly investment payback produced the same ranking. For the standard management strategy, installing a T18x15 spacing resulted $135 €$ ha-1 $^{-1}$ more expensive than installing a T18x18, while installing

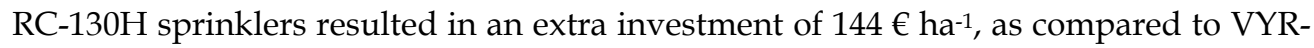


170 sprinklers. For this particular strategy, the choice of on-farm irrigation hardware did

2 not seem particularly relevant in terms of overall investment cost (less than $2 \%$ ).

\section{Distribution of the non suitable time for irrigation}

4

5 In the local conditions, windy periods can last for several days, seriously affecting

6 irrigation management. Consideration of suitable time for sprinkler irrigation at the

7 design phase will facilitate irrigation management when these events arise. However,

8 the coincidence of critical crop water requirements and long periods of high wind

$9 \quad$ speed will cause severe management problems.

Table 7 presents some statistics about the number of groups of $1 / 3,1,2,3$ and 4 contiguous days of unsuitable time for sprinkler irrigation. These data are presented for the two sprinkler types, the two sprinkler spacings, the two months (April and July) and the four management strategies. Data are presented in average, maximum, minimum and $20 \%$ return probability terms. Although the discussion below focuses on the $20 \%$ return probability, all four statistics are presented to illustrate the variability in windy periods.

For the four analysed strategies, April is the most critical month in terms of contiguous non adequate days for irrigation. These data confirm the previous discussion abut wind in April (see Tables 2 to 5). Although evapotranspiration is low in April, water application in the area is relevant in many crops due to emergence irrigations and soil water recharge at the beginning of the season (Figure 1). This is why the analysis of this month is conducted in parallel to July, the month showing critical water requirements. 
1

2 design. As a consequence, the results of this analysis are the same for the four on-farm

3 design configurations. Using the $20 \%$ return probability statistic, 30 groups of $1 / 3$ day

4 (8 contiguous hours), 4 groups of 1 day, and 1 group of 2 days of non suitable irrigation

5 time were detected in July. Since the network design criterion for this strategy is $56 \%$

6 suitable hours (13.4 hours of average daily operation), short windy periods ( $1 / 3$ day)

7 should be easy to accommodate in the irrigation schedule. However, 1 and 2 days of

8 non-irrigation will induce a delay in the farm irrigation schedule that can result in

9 sustained water stress and yield reduction.

The standard strategy shows clear differences between on-farm configurations. The narrow sprinkler spacing (T18x15) results in shorter and less numerous groups of non adequate irrigation periods than the ample sprinkler spacing (for both sprinkler types). The best performing on-farm configuration, sprinkler VYR-70 arranged at T18x15, presents nine periods of $1 / 3$ days and one period of 1 day in July, using the $20 \%$ return probability statistic (Table 7). This distribution of non suitable periods does not seem to impose severe limitations to irrigation scheduling. However, since this combination of strategy and hardware is characterised by a network design criterion of $85 \%$ suitable hours ( 20.4 hours of average daily operation), overcoming the unsuitable periods may be challenging at some points during the season. The ample spacing configuration can impose limitations to irrigation scheduling, since 4 or 3 groups of 1 day and 1 group of 2 days of non suitable time for irrigation with $20 \%$ of return probability will arise in July.

The restrictive strategy presents the largest and most numerous groups of unsuitable periods for irrigation. Differences between on-farm hardware options are 
1 not very clear in this case. In general, $\mathrm{RC}-130 \mathrm{H}$ presents the non suitable hours for

2 irrigation arranged in shorter groups than VYR-70. The narrow spacing results more

3 advantageous than the ample spacing in terms of size and number of non suitable

4 irrigation periods (for both sprinkler types). As previously discussed, the

5 implementation of this strategy in the study area will be very costly and difficult to

6 manage.

9 this strategy is based on $5 \%$ to $31 \%$ non suitable time (depending on on-farm

10 hardware). Considering the best case, corresponding to a T18x15 spacing and a VYR-70

11 sprinkler, groups of more than 3 contiguous non-suitable hours can already result in

The relaxed strategy presents less and shorter groups of contiguous non management problems. Data not presented reveal that 5 groups of 3 hours will be present in July with a $20 \%$ return probability. The number of groups is reduced to 2 when considering periods of $1 / 3$ day (Table 7 ).

In practical terms, a farmer can implement two management policies to cope with long windy periods. The first policy is to maintain soil water content high, particularly during the peak of the season, when the irrigation systems are working close to full capacity. In the central Ebro valley (and many other semiarid areas) this policy will not represent a significant contribution to the solution of the problem, since soil water retention is typically low (Cavero et al., 2003; Dechmi et al., 2003a). Additionally, this policy could result in deep percolation losses if a heavy rainfall occurred. The second policy is to adapt irrigation scheduling to the actual evolution of wind speed. This will require a very labour intensive irrigation scheduling. As presented in Figure, 3, local farmers modify their irrigation schedule in response to 
1 extreme wind events, and their modifications may result in 50\% decrease in water

2 delivery. In our opinion, wind-sensitive irrigation programmers are required in the

3 study area to perform these scheduling adaptations in an automatic fashion.

4

Since these management policies will not work to perfection in many practical

5 situations, designers should further decrease the percentage of suitable time for

6 irrigation presented in Figure 4 . This reduction will provide the slack required to deal

Eliminado:

7 with long windy periods. Additionally, a minimum time for network maintenance and

8 repairs must be considered at the design phase. If the percentage of suitable time is

9 low, these operations can be performed during windy periods. The combination of

10 these design and management rules with an adequate on-farm irrigation scheduling

11 will guarantee uniform and efficient irrigation. 


\section{Conclusions}

The following can be concluded from this paper:

1. Farmers in the Montesnegros Irrigation District respond to very high wind speeds by reducing water demand. However, they often irrigate under high winds (even exceeding $4.5 \mathrm{~m} \mathrm{~s}^{-1}$ ) due to limitations in the collective network capacity and to the difficulty of continuously adjusting their irrigation schedule to an unpredictable wind event.

2. A methodology has been proposed to link on-farm irrigation performance ( $\mathrm{CU}$ and WDEL) to hydrant operating time in windy irrigation districts. Three strategies based on irrigation performance were compared with a strategy based on a wind speed threshold.

3. Under the local conditions (meteorology and on-farm equipment), the strategy based on wind speed proved to be too restrictive, leading to low suitable time for irrigation (56\%). The standard strategy showed an average percentage of suitable time of $75 \%$. The different choices of sprinkler model and spacing resulted in a range of 63 to $85 \%$ suitable time for this strategy. The restrictive strategy resulted technically and economically unfeasible for the local conditions.

4. The applicability of the proposed method is subjected to the availability of wind speed records and $U-C U$ relationships for the local on-farm irrigation spacings and sprinklers. This information is not available in most sprinkler irrigated areas in our environment. Our results suggest that wind speed is the most important factor, followed by the choice of sprinkler spacing, and finally by the sprinkler model.

5. The proposed design methodology could be improved by linking irrigation performance to crop performance, using a crop model. In this way, the irrigation structures could be designed to meet crop yield or water productivity targets. 
1 6. Sustainable sprinkler irrigated agriculture in windy areas will require proper

2 design and management. Flexible networks, designed to apply crop water

3 requirements in periods of low wind, will not result in high efficiency unless

4 farmers apply wind-wise irrigation scheduling. New irrigation programmers are

5 required that incorporate wind sensors and produce real-time irrigation schedules

6 optimizing irrigation performance, crop yield or water productivity.

\section{$7 \quad$ Acknowledgement}

8

This research was funded by the CICYT of the Government of Spain through

9 grant AGL2004-06675-C03-03/AGR and by the Government of Aragón through grant

10 PIP090/2005. We are very grateful to the Montesnegros Irrigation District (Bujaraloz,

11 Zaragoza, Spain) for their co-operation in data retrieval and for their support in the

12 field work. Thanks are particularly due to the district manager, Carmelo Lorente. 


\section{$1 \quad$ References}

2 Alperovits, E. and Shamir, U., 1977. Design of optimal water distribution systems. Utah, USA.

Burt, C. M., Clemmens, A. J., Strelkoff, T. S., Solomon, K. H., Bliesner, R. D., A., H. L.,

Howell, T. A. and Eisenhauer, D. E., 1997. Irrigation performance measures: efficiency and uniformity. J. Irrig. Drainage Eng-ASCE, 123_(6) 423-442.

Carrión, P., Tarjuelo, J. M. and Montero, J., 2001. SIRIAS: a simulation model for sprinkler irrigation: I. Description of the model. Irrig. Sci., 2001_(20) 73-84.

Cavero, J., Beltrán, A. and Aragüés, R., 2003. Nitrate exported in the drainage waters of

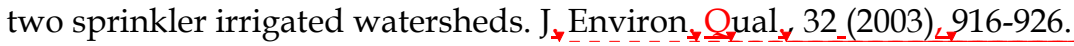

Clément, R. 1966. Calcul des débits dans les réseaux d'irrigation fonctionnant à la demande. Houille Blanche, 5, 553-575.

Clément, R., and Galand, A. 1979. Irrigation par aspersion et réseaux collectifs de distribution sous presion. Eyrolles Editeur, Paris.

Dechmi, F., Playán, E., Faci, J. M. and Tejero, M., 2003a. Analysis of an irrigation district in northeastern Spain: I: Characterisation and water use assessment. Agric, Water Manage., 61_(2003),75-92.

Dechmi, F., Playán, E., Cavero, J., Faci, J. M. and Martínez-Cob, A., 2003b. Wind effects

Eliminado:

Eliminado: .

Eliminado: ngrg.,

Eliminado: :

Eliminado:

Eliminado: :

Eliminado:

\begin{tabular}{|l|}
\hline Eliminado: ournal of \\
\hline Eliminado: mental \\
\hline Eliminado: $\mathrm{q}$ \\
\hline Eliminado: ity \\
\hline Eliminado: :
\end{tabular}

Eliminado: ó

Eliminado:

Eliminado: ic

Eliminado:

Eliminado: :

Eliminado: on solid set sprinkler irrigation depth and corn yield. Irrig. Sci., 22, 67-77. 
1 Dechmi, F., Playán, E., Cavero, J., Martínez-Cob, A. and Faci, J. M., 2004. A coupled crop and solid ser sprinkler simulation model: II. Model application. I. Irrig. Drainage Eng-ASCE, 130_(6) $511-519$.

D'Urso, G., Menenti, M., and Santini, A. 1995. Remote sensing and simulation modelling for on-demand irrigation systems management. Proceedings of the ICID/FAO Workshop on Irrigation Scheduling. 12-13 September 1995. Rome, Italy.

Farmani, R., Walters, G.A. and Savic, D. A., 2005.Trade-off between Total Cost and Reliability for Anytown Water Distribution Network. I. Water Resour. Plan.

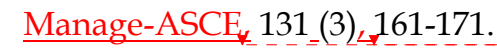

Frost, K. R. and Schwalen, H. C., 1955. Sprinkler evaporation losses. Agricultural Engineering, 36_(8), 526-528.

Fukui, Y., Nakanishi, K. and Okamura, S., 1980. Computer evaluation of sprinkler irrigation uniformity. Irrig. Sci., 2_23-32.

Goulter, I.C. and Morgan, D.R., 1985. An integrated approach to the layout \& design of water distribution networks. Civil Eng. Systems, 2_(2), 104-113.

Hargreaves, G.L., and Samani, Z.A., 1985. Reference crop evapotranspiration from temperature. Appl. Eng. Agric. 1 (2), 96-99.

Keller, J. and Bliesner, R. D., 1990. Sprinkler and trickle irrigation. Van Nostrand Reinhold, New York, NY, USA. 652 pp.

Lamaddalena, N. and Sagardoy, J. A. 2000. Performance analysis of on-demand pressurized irrigation systems. Irrigation and Drainage paper, 59. Food and Agricultural Organization (FAO). Rome, Italy. 133 pp.

Lansey, K.E., Duan, N., Mays, L.W. and Tung, Y.K., 1989. Water distribution system design under uncertainities. J. Water Resour. Plan. Manage-ASCE 115 (5)_630-645.

Lansey, K. E., 2000. Optimal design of water distribution systems. In L.W Mays, Editor,

Eliminado: J. Water Resour. Plng. and Mgmt.,

Eliminado: :

Eliminado:

Eliminado: :

Eliminado:

Eliminado: Water Distribution System Handbook. MacGraw-Hill. 912 pp. 
1 Li, J. (1998). Modeling crop yield as affected by uniformity of sprinkler irrigation

2 system. Agric. Water Manage, $38_{4}$ 135-146.

3 Lorenzini, G., 2004. Simplified modelling of sprinkler droplet dynamics. Biosystems 4 Engineering, 87_(1) 1-11.

5 Martínez-Cob, A., Zapata, N., Sánchez, I., Playán, E., Salvador, R. and Faci, J.M., 2005.

6

$$
\text { Variabilidad espacio-temporal de las pérdidas potenciales por evaporación y }
$$$$
\text { arrastre en el Valle medio del Ebro. In XXIII Congreso Nacional de Riegos y }
$$$$
\text { Drenajes, Elche, Alicante (Spain). }
$$

Monserrat J., Poch, R., Colomer M.A. and Mora F., 2004. Analysis of Clèment's first Formula for Irrigation Distribution Networks. J. Irrig. Drainage Eng-ASCE, 130 (2), 99-105.

Montero, J., Tarjuelo, J.M., and Carrión, P., 2001. SIRIAS: a simulation model for sprinkler irrigation: II. Calibration and validation of the model. Irrig. Sci. 20 (2), 8598.

Planells, P., Carrión P., Ortega, J.F., Moreno, M.A., and Tarjuelo J.M., 2005. Pumping Selection and Regulation for Water-Distribution Networks. I. Irrig. Drainage EngASCE $131(3), 273-281$.

Playán, E., Salvador, R., Faci, J. M., Zapata, N., Martínez-Cob, A. and Sánchez, I., 2005. Day and night wind drift and evaporation losses in sprinkler solid-sets and moving laterals. Agric. Water Manage 76 (2005) $139-159$.

Playán E., Cavero, J., Mantero, I.», Salvador, R., Lecina, S. , Faci, J. M., Andrés, J., Salvador, V., Cárdena, G., Ramón, S., Lacueva, J. L., Tejero, M., Ferri, J. and Martínez-Cob, A., 200Xa. A Specialized Database for the Management of Irrigation

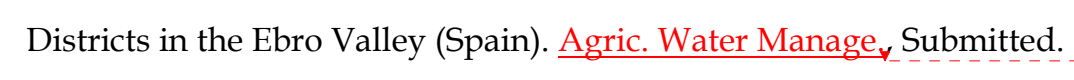

Eliminado: Agric. Wat.
Con formato: Inglés (Reino Unido)

Eliminado: J. Irrig. Drain. Engrg., ASCE

Con formato: Inglés (Reino Unido)

Con formato: Español (España - alfab. internacional)
Eliminado: J. Irrig. Drain. Engrg., ASCE

Eliminado: :
Eliminado: Agric. Wat.

Manage.

Eliminado: :

Eliminado:

Eliminado:

Eliminado:

Eliminado: Agric. Wat. Manage. 
1 Playán, E., Zapata, N., Faci, J. M., Tolosa, D., Lacueva, J. L., Pelegrín, J., Salvador, R.,

Sánchez, I. and Lafita, A., 200Xb. Assessing sprinkler irrigation uniformity using a ballistic simulation model. Agric. Water Manage, Submitted.

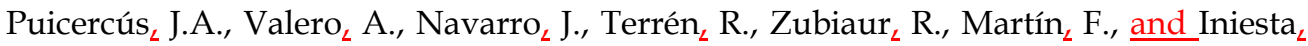
G. (1994), Atlas Eólico de Aragón. Diputación General de Aragón, Departamento de Industria, Comercio y Turismo, Zaragoza, Spain. 127 pp.

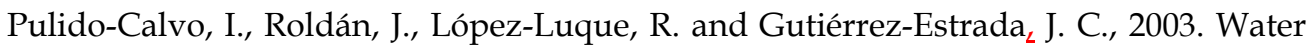
Delivery System Planning Considering Irrigation Simultaneity. I. Irrig. Drainage Eng-ASCE ${ }_{4} 129$

Savic, D.A. and Walters, G.A., 1997. Genetic algorithms for least-cost design of water distribution networks. J. Water Resour. Plan. Manage-ASCE, 123_(2), 67-77.

Tarjuelo, J. M., Valiente ${ }_{L}$ M. and Lozoya $L_{L_{2}} 1992$. Working conditions of sprinkler to optimize application of water. J. Irrig. Drainage Eng-ASCE 118 (6) 895-913.

Tarjuelo, J. M., Ortega, J. F., Montero, J. and de Juan, J. A., 2000. Modelling evaporation and drift losses in irrigation with medium size impact sprinklers under semi-arid conditions. Agric. Water Manage. 43 _(2000),263-284.

Tejero, M., 2003. Cálculo de la variabilidad temporal de las necesidades hídricas de los cultivos en las comarcas de Aragón. Graduation thesis, University of Lleida. Lleida, Spain. 287 pp.

Vories, E. D., Von Bernuth, R. D., and Mickelson, R. H., 1987. Simulating sprinkler performance in wind. J. Irrig. Drainage Eng-ASCE, 113_(1), 119-130.
Con formato: Español (España - alfab. internacional)

Eliminado: Agric. Wat.

Manage.
Eliminado: J. Irrig. Drain. Engrg., ASCE,

Eliminado: :

Eliminado: Journal of Water Res. Planning \& Management

Eliminado: J.

Eliminado: (

Eliminado: )

Eliminado: J. Irrig. Drain.

Engrg., ASCE

Eliminado: :

Eliminado:

Eliminado: Agric. Wat. Manage.

Eliminado: 


\section{$1 \quad$ List of Tables}

2 Table 1. Average daily water deliveries $\left(\mathrm{L} \mathrm{s}^{-1}\right)$ and ratios for periods with wind speeds below or over thresholds of 3.0 and $4.5 \mathrm{~m} \mathrm{~s}^{-1}$ and for day and night time. Data are presented for April and July of the 2001 and 2002 irrigation seasons.

Table 2. Monthly percentage of suitable hours for sprinkler irrigation for the eleven season data set at the Montesnegros Irrigation District, calculated as the number of hours with average wind speed lower than $3 \mathrm{~m} \mathrm{~s}^{-1}$. The monthly average and the 20\% return probability are also presented.

Table 3. Monthly percentage of suitable hours for sprinkler irrigation for the eleven season data set at the Montesnegros Irrigation District. Data are presented for two sprinkler types (VYR70 and $\mathrm{RC}-130 \mathrm{H}$ ) and two triangular sprinkler spacings (T18x18 and T18x15) for the standard management strategy. The monthly average and the $20 \%$ return probability $(20 \%$ $R P)$ are also presented.

Table 4. Monthly percentage of suitable hours for sprinkler irrigation for the eleven season data set at the Montesnegros Irrigation District. Data are presented for two sprinkler types (VYR70 and RC-130H)and two triangular sprinkler spacings (T18x18 and T18x15) for the restrictive management strategy. The monthly average and the $20 \%$ return probability $(20 \%$ $R P)$ are also presented.

Table 5. Monthly percentage of suitable hours for sprinkler irrigation for the eleven season data set at the Montesnegros Irrigation District. Data are presented for two sprinkler types (VYR70 and $\mathrm{RC}-130 \mathrm{H}$ ) and two triangular sprinkler spacings (T18x18 and T18x15) for the relaxed management strategy. The monthly average and the $20 \%$ return probability $(20 \%$ $R P)$ are also presented.

Table 6. Average wind speed (U) Coefficient of Uniformity (CU), Wind Drift and Evaporation Losses (WDEL) irrigation investment (network, on-farm and total), and yearly investment payback determined for the four discussed management strategies and their combinations of sprinkler type and spacing.

Table 7. Number of groups of 1/3, 1, 2, 3 and 4 days non suitable for sprinkler irrigation for two sprinkler types and two sprinkler spacings. The average, maximum, minimum and $20 \%$ 
1 return probability $(20 \%$ RP) statistics are presented for April and July for the four 2 management strategies. 
1 Table 1. Average daily water deliveries $\left(L^{-1}\right)$ and ratios for periods with wind speeds below or 2 over thresholds of 3.0 and $4.5 \mathrm{~m} \mathrm{~s}^{-1}$ and for day and night time. Data are presented for April 3 and July of the 2001 and 2002 irrigation seasons.

4

\begin{tabular}{|c|c|c|c|c|c|c|}
\hline & \multicolumn{3}{|c|}{ April } & \multicolumn{3}{|c|}{ July } \\
\hline & 2001 & 2002 & Average & 2001 & 2002 & Average \\
\hline $\mathrm{U} \leqq 3 \mathrm{~m} \mathrm{~s}^{-1}$ & 1,681 & 1,032 & 1,262 & 2,852 & 2,748 & 2,807 \\
\hline $\mathrm{U}>3 \mathrm{~m} \mathrm{~s}^{-1}$ & 1,128 & 638 & 945 & 2,485 & 2,599 & 2,557 \\
\hline $\mathrm{U}>3 / \mathrm{U} \leq 3$ & 0.67 & 0.62 & 0.75 & 0.87 & 0.95 & 0.91 \\
\hline $\mathrm{U} \leqq 4.5 \mathrm{~m} \mathrm{~s}^{-1}$ & 1,510 & 985 & 1,208 & 2,822 & 2,722 & 2,349 \\
\hline $\mathrm{U}>4.5 \mathrm{~m} \mathrm{~s}^{-1}$ & 1,022 & 438 & 828 & 2,092 & 2,539 & 2,290 \\
\hline $\mathrm{U}>4.5 / \mathrm{U} \leq 4.5$ & 0.68 & 0.44 & 0.69 & 0.74 & 0.93 & 0.87 \\
\hline Day & 1,273 & 823 & 1,328 & 2,662 & 2,543 & 2,240 \\
\hline Night & 1,369 & 945 & 884 & 2,863 & 2,830 & 2,446 \\
\hline Day/Night & 0.93 & 0.87 & 0.90 & 0.93 & 0.89 & 0.91 \\
\hline Average & 1,323 & 884 & 1,100 & 2,762 & 2,686 & 2,724 \\
\hline
\end{tabular}

Eliminado: $<=$ Eliminado: $<=$ Eliminado: > Eliminado: $<=$ Eliminado: $<=$ Eliminado: > Eliminado: Night Eliminado: Day 
1 Table 2. Monthly percentage of suitable hours for sprinkler irrigation for the eleven season data 2 set at the Montesnegros Irrigation District, calculated as the number of hours with average 3 wind speed lower than $3 \mathrm{~m} \mathrm{~s}^{-1}$. The monthly average and the 20\% return probability are also 4 presented.

5

\begin{tabular}{ccccccc}
\hline Year & $\begin{array}{c}\text { APR } \\
(\mathbf{\%})\end{array}$ & $\begin{array}{c}\text { MAY } \\
(\mathbf{\%})\end{array}$ & $\begin{array}{c}\text { JUN } \\
(\mathbf{\%})\end{array}$ & $\begin{array}{c}\text { JUL } \\
(\mathbf{\%})\end{array}$ & $\begin{array}{c}\text { AUG } \\
(\mathbf{\%})\end{array}$ & $\begin{array}{c}\text { SEPT } \\
(\mathbf{\%})\end{array}$ \\
\hline 1993 & 53 & 66 & 60 & 58 & 87 & 80 \\
1994 & 38 & 63 & 47 & 56 & 45 & 74 \\
1995 & 65 & 73 & 71 & 65 & 61 & 51 \\
1996 & 59 & 69 & 65 & 64 & 69 & 58 \\
1997 & 66 & 73 & 64 & 63 & 85 & 86 \\
1998 & 48 & 63 & 62 & 48 & 60 & 61 \\
1999 & 51 & 64 & 70 & 66 & 83 & 85 \\
2000 & 56 & 75 & 64 & 53 & 68 & 76 \\
2001 & 37 & 80 & 67 & 76 & 73 & 60 \\
2002 & 63 & 49 & 61 & 58 & 65 & 78 \\
2003 & 68 & 60 & 79 & 74 & 93 & 80 \\
\hline Average & 55 & 67 & 65 & 62 & 72 & 72 \\
$20 \%$ RP & 48 & 63 & 61 & 56 & 61 & 60 \\
\hline
\end{tabular}


1 Table 3. Monthly percentage of suitable hours for sprinkler irrigation for the eleven season data

2 set at the Montesnegros Irrigation District. Data are presented for two sprinkler types (VYR-

370 and $\mathrm{RC}-130 \mathrm{H}$ ) and two triangular sprinkler spacings (T18x18 and T18x15) for the

4 standard management strategy. The monthly average and the $20 \%$ return probability $(20 \%$

$5 \quad R P)$ are also presented.

6

\begin{tabular}{|c|c|c|c|c|c|c|c|c|c|c|c|c|c|}
\hline \multirow[b]{2}{*}{ Spacing } & \multirow[b]{2}{*}{ Year } & \multicolumn{6}{|c|}{ VYR-70 } & \multicolumn{6}{|c|}{$\mathrm{RC}-130 \mathrm{H}$} \\
\hline & & $\begin{array}{c}\text { APR } \\
(\%)\end{array}$ & $\begin{array}{c}\text { MAY } \\
(\mathbf{0})\end{array}$ & $\begin{array}{c}\text { JUN } \\
(\%)\end{array}$ & $\begin{array}{c}\text { JUL } \\
(\%)\end{array}$ & $\begin{array}{c}\text { AUG } \\
(\%)\end{array}$ & $\begin{array}{l}\text { SEP } \\
\mathbf{( \% )}\end{array}$ & $\begin{array}{c}\text { APR } \\
(\%)\end{array}$ & $\begin{array}{c}\text { MAY } \\
(\mathbf{( \% )}\end{array}$ & $\begin{array}{c}\text { JUN } \\
(\%)\end{array}$ & $\begin{array}{l}\text { JUL } \\
(\%)\end{array}$ & $\begin{array}{c}\text { AUG } \\
(\%)\end{array}$ & $\begin{array}{l}\text { SEP } \\
(\mathbf{0})\end{array}$ \\
\hline \multirow{13}{*}{$\begin{array}{l}\underset{\infty}{*} \\
\underset{\infty}{\infty} \\
\underset{-1}{H}\end{array}$} & 1993 & 61 & 80 & 73 & 83 & 96 & 86 & 53 & 70 & 66 & 73 & 94 & 82 \\
\hline & 1994 & 42 & 74 & 61 & 77 & 62 & 79 & 39 & 66 & 52 & 65 & 50 & 76 \\
\hline & 1995 & 72 & 82 & 81 & 81 & 78 & 64 & 67 & 77 & 75 & 73 & 68 & 56 \\
\hline & 1996 & 69 & 79 & 76 & 80 & 82 & 70 & 62 & 72 & 69 & 69 & 75 & 62 \\
\hline & 1997 & 74 & 84 & 77 & 75 & 94 & 93 & 70 & 77 & 69 & 67 & 90 & 89 \\
\hline & 1998 & 55 & 73 & 74 & 68 & 71 & 70 & 49 & 67 & 67 & 56 & 64 & 64 \\
\hline & 1999 & 56 & 74 & 85 & 83 & 94 & 91 & 52 & 67 & 77 & 72 & 89 & 88 \\
\hline & 2000 & 64 & 83 & 85 & 67 & 84 & 82 & 58 & 78 & 81 & 59 & 76 & 79 \\
\hline & 2001 & 45 & 85 & 78 & 86 & 85 & 71 & 39 & 82 & 73 & 81 & 79 & 64 \\
\hline & 2002 & 68 & 57 & 74 & 70 & 76 & 85 & 64 & 51 & 68 & 63 & 68 & 80 \\
\hline & 2003 & 73 & 72 & 92 & 89 & 98 & 88 & 69 & 66 & 85 & 78 & 96 & 83 \\
\hline & Average & 62 & 77 & 78 & 78 & 84 & 80 & 57 & 70 & 71 & 69 & 77 & 75 \\
\hline & $20 \%$ RP & 55 & 73 & 74 & 70 & 76 & 70 & 49 & 66 & 67 & 63 & 68 & 64 \\
\hline \multirow{13}{*}{$\begin{array}{l}\stackrel{10}{\not} \\
\underset{\infty}{\infty} \\
\underset{1}{H}\end{array}$} & 1993 & 84 & 92 & 84 & 87 & 99 & 94 & 81 & 92 & 81 & 86 & 99 & 93 \\
\hline & 1994 & 56 & 86 & 76 & 91 & 84 & 87 & 51 & 85 & 73 & 88 & 77 & 85 \\
\hline & 1995 & 89 & 91 & 89 & 92 & 90 & 80 & 85 & 89 & 87 & 90 & 87 & 78 \\
\hline & 1996 & 84 & 90 & 88 & 91 & 93 & 83 & 81 & 88 & 85 & 89 & 90 & 81 \\
\hline & 1997 & 87 & 94 & 89 & 86 & 97 & 98 & 83 & 92 & 86 & 84 & 96 & 97 \\
\hline & 1998 & 72 & 89 & 88 & 80 & 88 & 81 & 70 & 87 & 85 & 77 & 85 & 77 \\
\hline & 1999 & 72 & 88 & 96 & 92 & 99 & 96 & 69 & 85 & 95 & 90 & 99 & 96 \\
\hline & 2000 & 85 & 93 & 93 & 77 & 94 & 90 & 82 & 92 & 91 & 74 & 92 & 88 \\
\hline & 2001 & 66 & 93 & 87 & 92 & 94 & 83 & 62 & 91 & 86 & 92 & 91 & 81 \\
\hline & 2002 & 84 & 77 & 82 & 85 & 87 & 93 & 81 & 73 & 81 & 81 & 84 & 92 \\
\hline & 2003 & 85 & 88 & 98 & 98 & 100 & 96 & 82 & 84 & 98 & 96 & 100 & 95 \\
\hline & Average & 78 & 89 & 88 & 88 & 93 & 89 & 75 & 87 & 86 & 86 & 91 & 88 \\
\hline & $20 \%$ RP & 72 & 88 & 84 & 85 & 88 & 83 & 69 & 85 & 81 & 81 & 85 & 81 \\
\hline
\end{tabular}


1 Table 4. Monthly percentage of suitable hours for sprinkler irrigation for the eleven season data

2 set at the Montesnegros Irrigation District. Data are presented for two sprinkler types (VYR-

370 and RC-130H)and two triangular sprinkler spacings (T18x18 and T18x15) for the

4 restrictive management strategy. The monthly average and the 20\% return probability $(20 \%$

$5 \quad R P)$ are also presented.

6

\begin{tabular}{|c|c|c|c|c|c|c|c|c|c|c|c|c|c|}
\hline \multirow[b]{2}{*}{ Spacing } & \multirow[b]{2}{*}{ Year } & \multicolumn{6}{|c|}{ VYR-70 } & \multicolumn{6}{|c|}{ RC-130H } \\
\hline & & $\begin{array}{l}\text { APR } \\
\text { (\%) }\end{array}$ & $\begin{array}{c}\text { MAY } \\
(\%)\end{array}$ & $\begin{array}{c}\text { JUN } \\
(\%)\end{array}$ & $\begin{array}{l}\text { JUL } \\
(\%)\end{array}$ & $\begin{array}{c}\text { AUG } \\
(\%)\end{array}$ & $\begin{array}{l}\text { SEP } \\
(\%)\end{array}$ & $\begin{array}{c}\text { APR } \\
(\%)\end{array}$ & $\begin{array}{c}\text { MAY } \\
(\mathbf{\%})\end{array}$ & $\begin{array}{c}\text { JUN } \\
(\%)\end{array}$ & $\begin{array}{l}\text { JUL } \\
(\%)\end{array}$ & $\begin{array}{l}\text { AUC } \\
(\%)\end{array}$ & $\begin{array}{r}\text { SEP } \\
(\%)\end{array}$ \\
\hline & 1993 & 25 & 43 & 39 & 10 & 15 & 60 & 26 & 41 & 31 & 22 & 62 & 42 \\
\hline & 1994 & 26 & 38 & 30 & 31 & 28 & 63 & 21 & 35 & 26 & 31 & 25 & 33 \\
\hline & 1995 & 45 & 44 & 52 & 41 & 38 & 28 & 35 & 43 & 42 & 37 & 31 & 30 \\
\hline & 1996 & 35 & 47 & 40 & 41 & 46 & 41 & 29 & 39 & 38 & 32 & 35 & 29 \\
\hline & 1997 & 49 & 51 & 43 & 43 & 67 & 62 & 27 & 40 & 31 & 32 & 36 & 52 \\
\hline & 1998 & 28 & 39 & 42 & 24 & 42 & 41 & 28 & 34 & 35 & 25 & 33 & 39 \\
\hline & 1999 & 34 & 44 & 45 & 45 & 62 & 71 & 26 & 34 & 34 & 33 & 47 & 41 \\
\hline & 2000 & 33 & 53 & 15 & 34 & 33 & 56 & 31 & 44 & 32 & 33 & 41 & 45 \\
\hline & 2001 & 22 & 60 & 49 & 57 & 54 & 40 & 20 & 45 & 39 & 44 & 43 & 28 \\
\hline & 2002 & 42 & 30 & 40 & 39 & 45 & 58 & 35 & 32 & 37 & 32 & 37 & 37 \\
\hline & 2003 & 52 & 37 & 57 & 56 & 79 & 60 & 36 & 34 & 44 & 38 & 46 & 42 \\
\hline & Avera & 35 & 44 & 41 & 38 & 46 & 53 & 29 & 38 & 35 & 33 & 40 & 38 \\
\hline & $20 \% \mathrm{R}$ & 26 & 37 & 39 & 31 & 33 & 41 & 26 & 34 & 31 & 32 & 33 & 30 \\
\hline \multirow{13}{*}{ 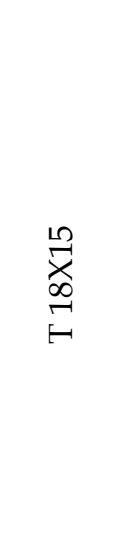 } & 1993 & 26 & 45 & 42 & 11 & 30 & 62 & 31 & 30 & 24 & 39 & 61 & 24 \\
\hline & 1994 & 27 & 40 & 32 & 35 & 31 & 64 & 15 & 30 & 23 & 30 & 21 & 21 \\
\hline & 1995 & 46 & 49 & 55 & 46 & 40 & 30 & 24 & 30 & 23 & 29 & 27 & 31 \\
\hline & 1996 & 36 & 49 & 43 & 45 & 49 & 42 & 25 & 25 & 28 & 27 & 25 & 23 \\
\hline & 1997 & 51 & 53 & 45 & 46 & 71 & 66 & 18 & 23 & 23 & 25 & 19 & 24 \\
\hline & 1998 & 29 & 41 & 44 & 27 & 45 & 43 & 26 & 29 & 25 & 29 & 24 & 22 \\
\hline & 1999 & 35 & 45 & 48 & 48 & 65 & 72 & 19 & 23 & 28 & 28 & 23 & 15 \\
\hline & 2000 & 34 & 55 & 21 & 38 & 40 & 59 & 30 & 26 & 39 & 21 & 37 & 24 \\
\hline & 2001 & 23 & 62 & 52 & 61 & 58 & 43 & 19 & 23 & 25 & 21 & 21 & 23 \\
\hline & 2002 & 43 & 31 & 43 & 41 & 48 & 60 & 23 & 24 & 27 & 22 & 23 & 22 \\
\hline & 2003 & 53 & 40 & 61 & 59 & 82 & 62 & 21 & 26 & 25 & 24 & 17 & 22 \\
\hline & Avera & 37 & 46 & 44 & 42 & 51 & 55 & 23 & 26 & 26 & 27 & 27 & 23 \\
\hline & $20 \% \mathrm{RP}$ & 27 & 40 & 42 & 35 & 40 & 43 & 19 & 23 & 23 & 22 & 21 & 22 \\
\hline
\end{tabular}


1 Table 5. Monthly percentage of suitable hours for sprinkler irrigation for the eleven season data

2 set at the Montesnegros Irrigation District. Data are presented for two sprinkler types (VYR-

370 and RC-130H) and two triangular sprinkler spacings (T18x18 and T18x15) for the relaxed

4 management strategy. The monthly average and the $20 \%$ return probability $(20 \% R P)$ are

5 also presented.

6

\begin{tabular}{|c|c|c|c|c|c|c|c|c|c|c|c|c|c|}
\hline \multirow{2}{*}{\multicolumn{2}{|c|}{ Spacing Year }} & \multicolumn{6}{|c|}{ VYR-70 } & \multicolumn{6}{|c|}{ RC- $130 \mathrm{H}$} \\
\hline & & APR & MAY & JUN & JUL & AUG & SEP & APR & MAY & JUN & JUL & AUG & SEP \\
\hline \multirow{13}{*}{ 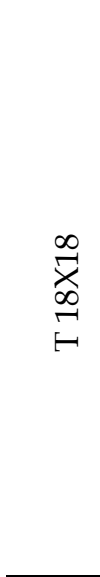 } & 1993 & 85 & 95 & 88 & 89 & 99 & 96 & 63 & 79 & 72 & 84 & 97 & 86 \\
\hline & 1994 & 56 & 90 & 80 & 94 & 89 & 88 & 42 & 74 & 61 & 74 & 61 & 79 \\
\hline & 1995 & 89 & 92 & 91 & 94 & 92 & 84 & 72 & 82 & 81 & 81 & 76 & 63 \\
\hline & 1996 & 86 & 91 & 90 & 93 & 96 & 86 & 70 & 80 & 75 & 78 & 81 & 71 \\
\hline & 1997 & 88 & 94 & 92 & 90 & 97 & 98 & 75 & 83 & 76 & 75 & 93 & 92 \\
\hline & 1998 & 75 & 90 & 90 & 82 & 92 & 83 & 56 & 73 & 73 & 67 & 70 & 69 \\
\hline & 1999 & 74 & 90 & 97 & 94 & 100 & 97 & 58 & 74 & 84 & 81 & 93 & 91 \\
\hline & 2000 & 87 & 96 & 95 & 80 & 96 & 92 & 66 & 83 & 85 & 66 & 84 & 83 \\
\hline & 2001 & 70 & 93 & 89 & 93 & 96 & 86 & 46 & 85 & 77 & 86 & 84 & 72 \\
\hline & 2002 & 85 & 80 & 85 & 88 & 89 & 94 & 69 & 58 & 73 & 69 & 76 & 86 \\
\hline & 2003 & 86 & 90 & 99 & 99 & 100 & 96 & 74 & 72 & 92 & 88 & 99 & 86 \\
\hline & Average & 80 & 91 & 91 & 91 & 95 & 91 & 63 & 77 & 77 & 77 & 83 & 80 \\
\hline & $20 \%$ RP & 74 & 90 & 88 & 88 & 92 & 86 & 56 & 73 & 73 & 69 & 70 & 71 \\
\hline \multirow{13}{*}{ 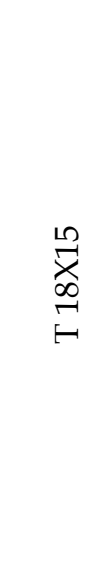 } & 1993 & 92 & 98 & 94 & 95 & 99 & 99 & 86 & 98 & 91 & 91 & 99 & 96 \\
\hline & 1994 & 70 & 95 & 92 & 100 & 97 & 94 & 55 & 90 & 83 & 97 & 95 & 90 \\
\hline & 1995 & 95 & 97 & 98 & 98 & 98 & 92 & 89 & 93 & 94 & 96 & 94 & 87 \\
\hline & 1996 & 91 & 96 & 96 & 96 & 99 & 93 & 86 & 91 & 92 & 95 & 97 & 88 \\
\hline & 1997 & 93 & 97 & 97 & 95 & 98 & 100 & 87 & 94 & 95 & 92 & 97 & 99 \\
\hline & 1998 & 86 & 97 & 95 & 93 & 98 & 90 & 76 & 92 & 92 & 85 & 95 & 84 \\
\hline & 1999 & 85 & 94 & 99 & 99 & 100 & 98 & 74 & 90 & 97 & 97 & 100 & 97 \\
\hline & 2000 & 94 & 98 & 98 & 88 & 98 & 96 & 88 & 97 & 95 & 82 & 97 & 94 \\
\hline & 2001 & 83 & 97 & 95 & 96 & 98 & 95 & 70 & 93 & 91 & 94 & 97 & 88 \\
\hline & 2002 & 93 & 89 & 90 & 95 & 93 & 98 & 85 & 80 & 84 & 91 & 88 & 95 \\
\hline & 2003 & 93 & 95 & 100 & 100 & 100 & 99 & 88 & 90 & 100 & 100 & 100 & 97 \\
\hline & Average & 89 & 96 & 96 & 96 & 98 & 96 & 80 & 92 & 92 & 93 & 96 & 92 \\
\hline & $20 \% \mathrm{RP}$ & 85 & 95 & 94 & 95 & 98 & 93 & 74 & 90 & 91 & 91 & 95 & 88 \\
\hline
\end{tabular}


1 Table 6. Average wind speed (U) Coefficient of Uniformity (CU), Wind Drift and Evaporation Losses (WDEL) irrigation investment (network, on-farm and total), and yearly investment payback determined for the four discussed management strategies and their combinations of sprinkler type and spacing.

\begin{tabular}{|c|c|c|c|c|c|c|c|c|c|}
\hline \multirow[b]{2}{*}{ Strategy } & \multirow[b]{2}{*}{$\begin{array}{l}\text { Sprinkler } \\
\text { model }\end{array}$} & \multirow[b]{2}{*}{$\begin{array}{c}\text { Sprinkler } \\
\text { Spacing }\end{array}$} & \multirow{2}{*}{$\begin{array}{c}\text { Average } \\
\mathrm{U} \\
\left(\mathrm{m} \mathrm{s}^{-1}\right)\end{array}$} & \multirow{2}{*}{$\begin{array}{c}\text { Average } \\
\text { CU } \\
(\%)\end{array}$} & \multirow{2}{*}{$\begin{array}{c}\text { Average } \\
\text { WDEL } \\
(\%)\end{array}$} & \multicolumn{3}{|c|}{ Investment } & \multirow{2}{*}{ 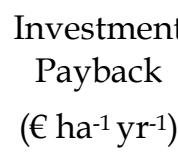 } \\
\hline & & & & & & $\begin{array}{c}\text { Network } \\
\left(€ \text { ha }^{-1}\right)\end{array}$ & $\begin{array}{l}\text { On-farm } \\
\left(€ \text { ha-1) }^{-1}\right.\end{array}$ & $\begin{array}{c}\text { Total } \\
\left(€ \text { ha }^{-1}\right)\end{array}$ & \\
\hline \multirow{4}{*}{$\mathrm{U}<3$} & \multirow{2}{*}{ VYR-70 } & T18x18 & 1.8 & 90.6 & 13.8 & 5,145 & 3,306 & 8,451 & 393.4 \\
\hline & & $\mathrm{T} 18 \times 15$ & 1.8 & 91.0 & 13.8 & 5,145 & 3,787 & 8,932 & 415.8 \\
\hline & \multirow{2}{*}{$\mathrm{RC}-130 \mathrm{H}$} & $\mathrm{T} 18 \times 18$ & 1.8 & 90.5 & 13.8 & 5,145 & 3,306 & 8,451 & 393.4 \\
\hline & & $\mathrm{T} 18 \times 15$ & 1.8 & 89.8 & 13.8 & 5,145 & 3,787 & 8,932 & 415.8 \\
\hline \multirow{4}{*}{ Standard } & \multirow{2}{*}{ VYR-70 } & $\mathrm{T} 18 \times 18$ & 2.0 & 89.9 & 13.6 & 4,756 & 3,306 & 8,062 & 375.3 \\
\hline & & $\mathrm{T} 18 \times 15$ & 2.3 & 89.9 & 13.7 & 4,450 & 3,787 & 8,237 & 383.4 \\
\hline & \multirow{2}{*}{$\mathrm{RC}-130 \mathrm{H}$} & $\mathrm{T} 18 \times 18$ & 1.8 & 90.2 & 13.4 & 4,940 & 3,306 & 8,246 & 383.8 \\
\hline & & $\mathrm{T} 18 \times 15$ & 2.2 & 89.8 & 13.7 & 4,554 & 3,787 & 8,341 & 388.3 \\
\hline \multirow{4}{*}{ Restrictive } & \multirow{2}{*}{ VYR-70 } & $\mathrm{T} 18 \times 18$ & 1.5 & 91.4 & 11.3 & 7,309 & 3,306 & 10,615 & 494.1 \\
\hline & & $\mathrm{T} 18 \times 15$ & 1.6 & 91.5 & 11.4 & 7,012 & 3,787 & 10,799 & 502.7 \\
\hline & \multirow{2}{*}{$\mathrm{RC}-130 \mathrm{H}$} & T18x18 & 1.9 & 91.8 & 11.0 & 7,250 & 3,306 & 10,556 & 491.4 \\
\hline & & $\mathrm{T} 18 \times 15$ & 2.6 & 91.8 & 11.5 & 8,204 & 3,787 & 11,991 & 558.2 \\
\hline \multirow{4}{*}{ Relaxed } & \multirow{2}{*}{ VYR-70 } & $\mathrm{T} 18 \times 18$ & 2.2 & 89.3 & 14.1 & 4,401 & 3,306 & 7,707 & 358.7 \\
\hline & & $\mathrm{T} 18 \times 15$ & 2.3 & 89.6 & 14.5 & 4,362 & 3,787 & 8,149 & 379.3 \\
\hline & \multirow{2}{*}{$\mathrm{RC}-130 \mathrm{H}$} & T18×18 & 2.0 & 89.5 & 14.4 & 4,763 & 3,306 & 8,069 & 375.6 \\
\hline & & $\mathrm{T} 18 \times 15$ & 2.4 & 89.4 & 15.1 & 4,299 & 3,787 & 8,086 & 376.4 \\
\hline
\end{tabular}


1 Table 7. Number of groups of 1/3, 1,2, 3 and 4 days non suitable for sprinkler irrigation for 2 two sprinkler types and two sprinkler spacings. The average, maximum, minimum and $20 \%$ 3 return probability $(20 \% R P)$ statistics are presented for April and July for the four 4 management strategies.

\begin{tabular}{|c|c|c|c|c|c|c|c|c|c|c|c|c|c|c|c|c|c|c|c|c|c|}
\hline \multirow{3}{*}{ 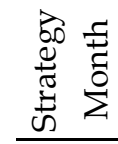 } & \multirow{3}{*}{ Statistics } & \multicolumn{10}{|c|}{ VYR-70 } & \multicolumn{10}{|c|}{ RC-130H } \\
\hline & & \multicolumn{5}{|c|}{ T18X18 } & \multicolumn{5}{|c|}{ T18X15 } & \multicolumn{5}{|c|}{ T18X18 } & \multicolumn{5}{|c|}{ T18X15 } \\
\hline & & $1 / 3$ & & 2 & 3 & 4 & $1 / 3$ & 1 & 2 & 3 & 4 & $1 / 3$ & 1 & 2 & 3 & & $1 / 3$ & & 2 & & 4 \\
\hline \multirow{8}{*}{ is } & Average & 28 & 5 & 1 & 0 & 0 & 28 & 5 & 1 & 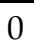 & 0 & 28 & 5 & & 0 & & 28 & 5 & 1 & 0 & 0 \\
\hline & Max & 47 & 12 & 4 & 2 & 1 & 47 & 12 & 4 & 2 & 1 & 47 & 12 & 4 & 2 & & 47 & 12 & 4 & 2 & 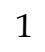 \\
\hline & Min & 18 & 2 & 0 & 0 & 0 & 18 & 2 & 0 & 0 & 0 & 18 & 2 & 0 & 0 & & 18 & 2 & 0 & 0 & 0 \\
\hline & $20 \% \mathrm{RP}$ & 41 & 7 & 2 & 1 & 0 & 41 & 7 & 2 & 1 & 0 & 41 & 7 & 2 & 1 & & 41 & 7 & 2 & 1 & 0 \\
\hline & Average & 22 & 3 & 1 & 0 & 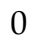 & 22 & 3 & 1 & 0 & 0 & 22 & 3 & 1 & 0 & & 22 & 3 & 1 & 0 & 0 \\
\hline & Max & 35 & 7 & 3 & 1 & 0 & 35 & 7 & 3 & 1 & 0 & 35 & 7 & 3 & 1 & & 35 & 7 & 3 & 1 & 0 \\
\hline & Min & 9 & 1 & 0 & 0 & 0 & 9 & 1 & 0 & 0 & 0 & 9 & 1 & 0 & 0 & & 9 & 1 & 0 & 0 & 0 \\
\hline & $20 \% \mathrm{RP}$ & 30 & 4 & 1 & 0 & 0 & 30 & 4 & 1 & 0 & & 30 & 4 & 1 & 0 & & 30 & 4 & 1 & 0 & 0 \\
\hline \multirow{8}{*}{ 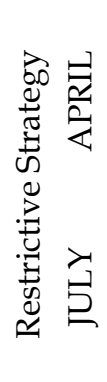 } & Aver & 55 & 10 & 3 & 1 & 0 & 53 & 10 & 3 & 1 & 0 & 55 & 9 & 3 & 1 & & 55 & 8 & 2 & 0 & 0 \\
\hline & Max & 63 & 14 & 8 & 2 & 2 & 60 & 12 & 5 & 2 & 1 & 65 & 12 & 6 & 2 & & 64 & 12 & 4 & 0 & 0 \\
\hline & Min & 41 & 4 & 1 & 0 & 0 & 39 & 4 & 1 & 0 & 0 & 41 & 5 & 1 & 0 & & 47 & 3 & 0 & 0 & 0 \\
\hline & $20 \% \mathrm{RP}$ & 62 & 12 & 5 & 2 & 1 & 58 & 12 & 4 & 2 & & 60 & 11 & 4 & 2 & & 59 & 10 & 3. & 0 & 0 \\
\hline & Average & 39 & 5 & 1 & 0 & 0 & 35 & 7 & 2 & 1 & & 35 & 5 & 1 & 0 & & 43 & 3 & 0 & 0 & 0 \\
\hline & Max & 59 & 8 & 3 & 2 & 1 & 54 & 15 & 6 & 3 & 0 & 57 & 8 & 3 & 2 & & 49 & 7 & 2 & 1 & 0 \\
\hline & Min & 23 & 2 & 0 & 0 & 0 & 19 & 2 & 0 & 0 & 0 & 20 & 2 & 0 & 0 & & 38 & 1 & 0 & 0 & 0 \\
\hline & $20 \% \mathrm{RP}$ & 45 & 9 & 3 & 1 & 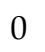 & 41 & 9 & 3 & 1 & ( & 40 & 6 & 1 & 1 & & 46 & 5 & 1 & 0 & 0 \\
\hline \multirow{8}{*}{ 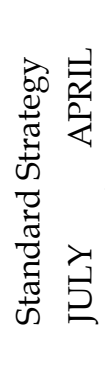 } & Ave & 23 & 5 & 1 & 0 & 0 & 12 & 2 & 0 & & 0 & 27 & 5 & 1 & 0 & & 15 & 3 & 0 & 0 & 0 \\
\hline & Max & 45 & 10 & 4 & 2 & 1 & 30 & 5 & 1 & & & 46 & 10 & 4 & 2 & & 34 & 6 & 2 & 0 & 0 \\
\hline & Mir & 14 & 2 & 0 & 0 & 0 & 5 & 0 & 0 & 0 & & 17 & 3 & 0 & 0 & & 7 & 1 & 0 & 0 & 0 \\
\hline & $20 \%$ RP & 27 & 6 & 1 & 0 & 0 & 18 & 4 & 1 & 0 & 0 & 33 & 7 & 2 & 1 & U & 20 & 4 & 1 & 0 & 0 \\
\hline & Average & 12 & 2 & 0 & 0 & 0 & 6 & 1 & 0 & 0 & & 16 & 3 & 7 & 0 & & 7 & 1 & 0 & 0 & 0 \\
\hline & Max & 23 & 5 & 2 & 0 & 0 & 15 & 3 & 1 & 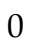 & & 28 & 7 & . & 1 & & 17 & 4 & 1 & 0 & 0 \\
\hline & Min & 4 & 0 & 0 & 0 & 0 & 0 & 0 & 0 & 0 & & 7 & 0 & 0 & 0 & & 0 & 0 & 0 & 0 & 0 \\
\hline & $20 \% \mathrm{RP}$ & 18 & 3 & 1 & 0 & 0 & 9 & 1 & 0 & 0 & & 24 & 4 & 1 & 0 & & 11 & 1 & 0 & 0 & 0 \\
\hline \multirow{8}{*}{ 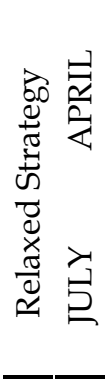 } & Aver & 12 & 2 & 0 & 0 & 0 & 5 & 0 & 0 & U & & 23 & 4 & 1 & 0 & & 11 & 2 & 0 & 0 & 0 \\
\hline & Max & 31 & 5 & 1 & 0 & 0 & 15 & 0 & 0 & 0 & & 45 & 10 & 4 & 2 & & 28 & 5 & 1 & 0 & 0 \\
\hline & Min & 4 & 0 & 0 & 0 & 0 & 1 & 0 & 0 & 0 & 0 & 14 & 2 & 0 & 0 & & 5 & 0 & 0 & 0 & 0 \\
\hline & $20 \% \mathrm{RP}$ & 17 & 3 & 1 & - & 0 & 6 & 0 & 0 & $\underline{-}$ & 0 & 27 & 6 & 1 & 0 & 0 & 18 & 4 & 0 & 0 & 0 \\
\hline & Average & 5 & 0 & 0 & 0 & 0 & 1 & 0 & 0 & 0 & 0 & 12 & 2 & 0 & 0 & & 4 & 1 & 0 & 0 & 0 \\
\hline & Max & 13 & 2 & 0 & 0 & 0 & 6 & 0 & 0 & 0 & C & 24 & 6 & 3 & 0 & & 12 & 3 & 1 & 0 & 0 \\
\hline & Min & 0 & 0 & 0 & 0 & 0 & 0 & 0 & 0 & 0 & & 2 & 0 & 0 & 0 & 0 & 0 & 0 & 0 & 0 & 0 \\
\hline & $20 \% \mathrm{RP}$ & 7 & 1 & 0 & 0 & 0 & 2 & 0 & 0 & 0 & & 19 & 3 & 1 & 0 & & 7 & 1 & 0 & 0 & \\
\hline
\end{tabular}




\section{$1 \quad$ List of Figures}

2 Figure 1. Daily Net Irrigation Requirements and Water deliveries at the Montesnegros 3 Irrigation District for the 2001 and 2002 irrigation seasons.

4 Figure 2. Monthly relative frequency of five wind speed ranges: lower than $1 \mathrm{~m} \mathrm{~s}^{-1}, 1-2 \mathrm{~m} \mathrm{~s}^{-1}$, $5 \quad 2-3 \mathrm{~m} \mathrm{~s}^{-1}, 3-4 \mathrm{~m} \mathrm{~s}^{-1} 4-5 \mathrm{~m} \mathrm{~s}^{-1}$, and higher than $5 \mathrm{~m} \mathrm{~s}^{-1}$, for the eleven year data set at the 6 Montesnegros Irrigation District.

7 Figure 3. Evolution of daily water delivery $\left(L^{-1}\right)$ and wind speed for April and July of 2001 8 and 2002 at the Montesnegros Irrigation District.

9 Figure 4. Suitable hours for irrigation (\%) in July for the four analysed strategies $\left(U<3 \mathrm{~m} \mathrm{~s}^{-1}\right.$, 10 standard, restrictive and relaxed). Results are presented for the two sprinkler models (VYR1170 and $\mathrm{RC}-130 \mathrm{H})$ and for the two sprinkler spacings: Ample (A, T18x18) and Narrow (N, 12 T18x15). 
1 Figure 1. Daily Net Irrigation Requirements and Water deliveries at the Montesnegros

2 Irrigation District for the 2001 and 2002 irrigation seasons.
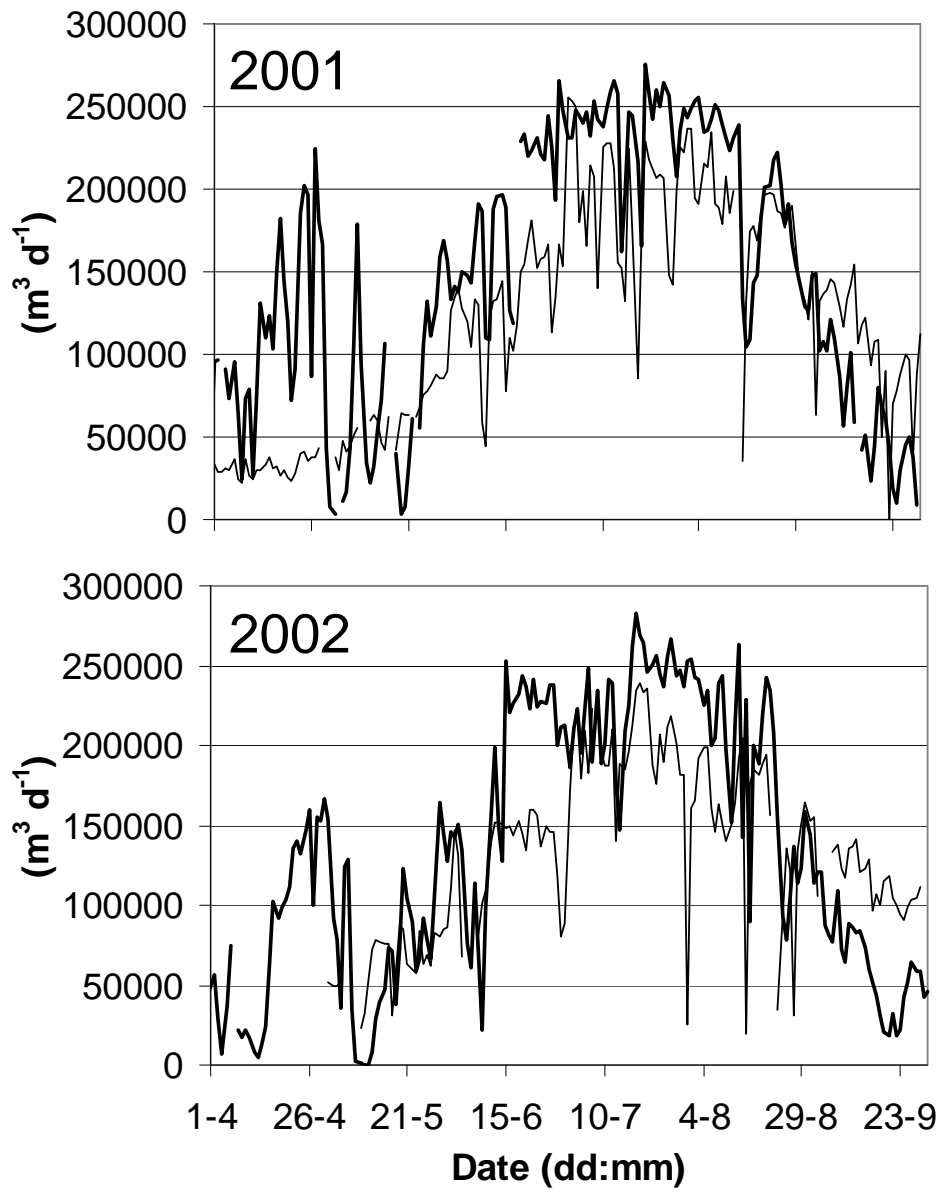
1 Figure 2. Monthly relative frequency of five wind speed ranges: lower than $1 \mathrm{~m} \mathrm{~s}^{-1}, 1-2 \mathrm{~m} \mathrm{~s}^{-1}$, $2 \quad 2-3 \mathrm{~m} \mathrm{~s}^{-1}, 3-4 \mathrm{~m} \mathrm{~s}^{-1} 4-5 \mathrm{~m} \mathrm{~s}^{-1}$, and higher than $5 \mathrm{~m} \mathrm{~s}^{-1}$, for the eleven year data set at the 3 Montesnegros Irrigation District.

4

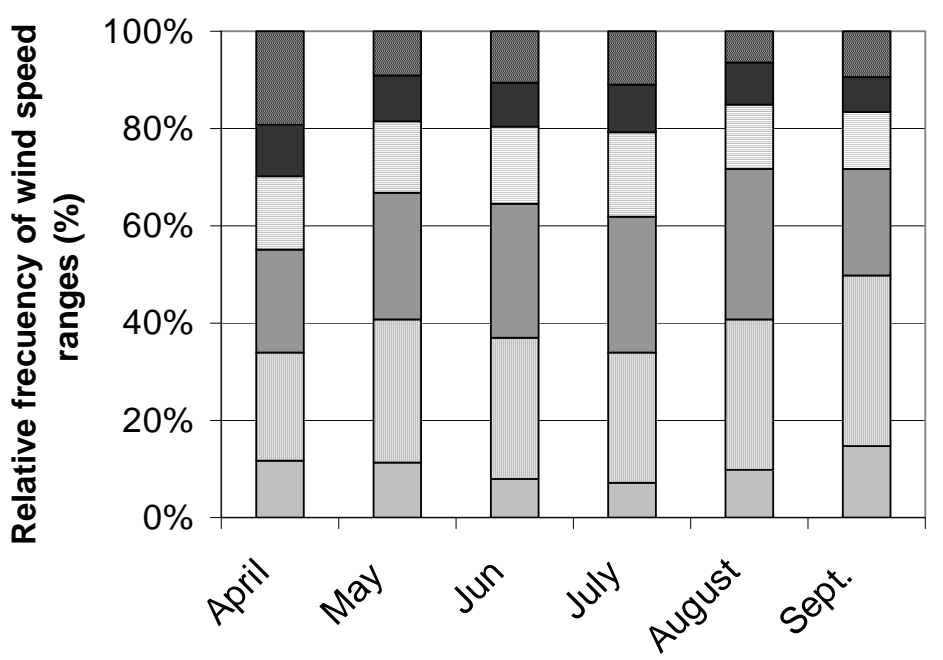

Month (mm) 
1

2 3

Figure 3. Evolution of daily water delivery $\left(\mathrm{L} \mathrm{s}^{-1}\right)$ and wind speed for April and July of 2001 and 2002 at the Montesnegros Irrigation District.

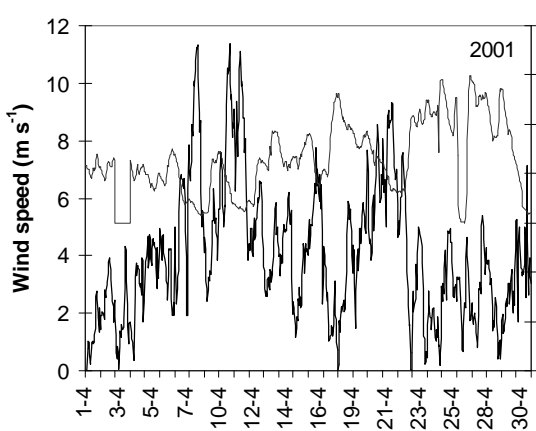

Date (dd-mm)

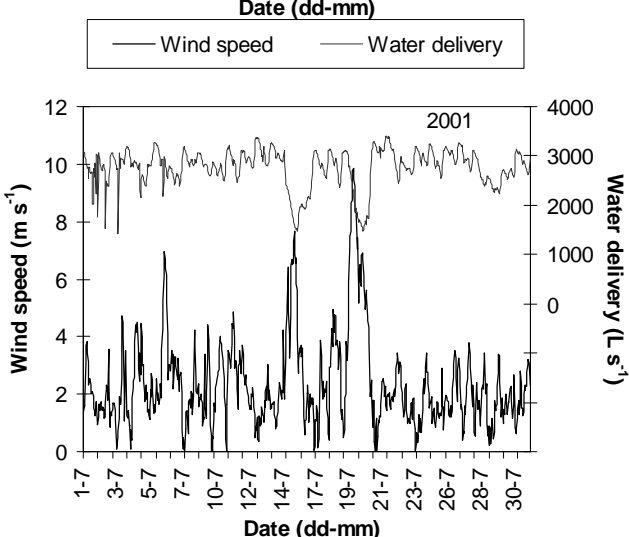

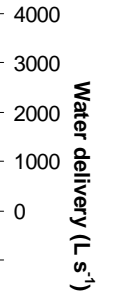
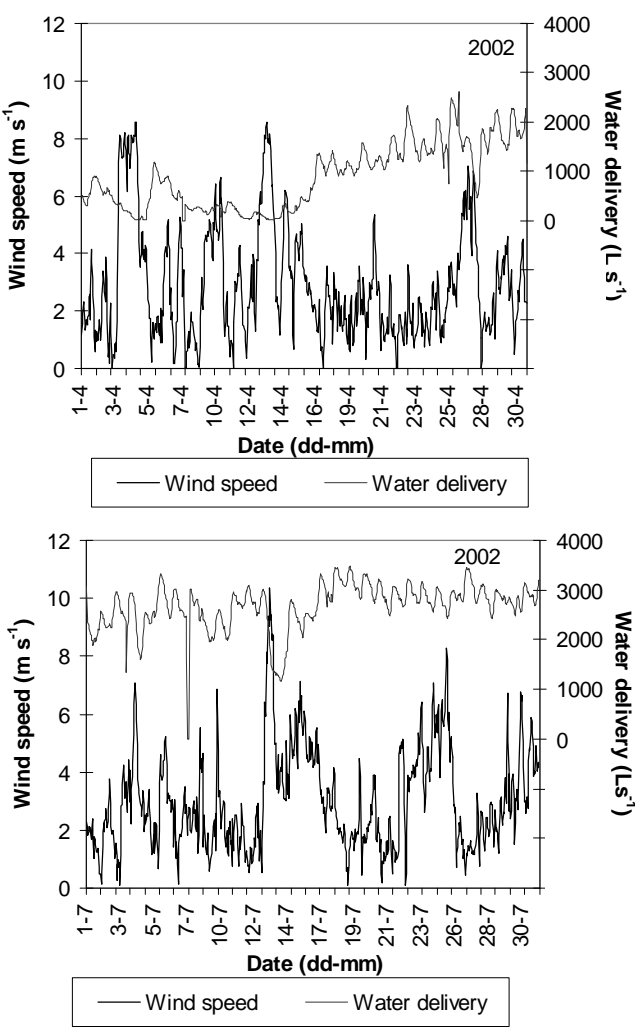
1 Figure 4. Suitable hours for irrigation (\%) in July for the four analysed strategies $\left(U<3 \mathrm{~m} \mathrm{~s}^{-1}\right.$,

2 standard, restrictive and relaxed). Results are presented for the two sprinkler models (VYR-70

3 and $\mathrm{RC}-130 \mathrm{H})$ and for the two sprinkler spacings: Ample (A, T18x18) and Narrow (N, 4 T18x15).

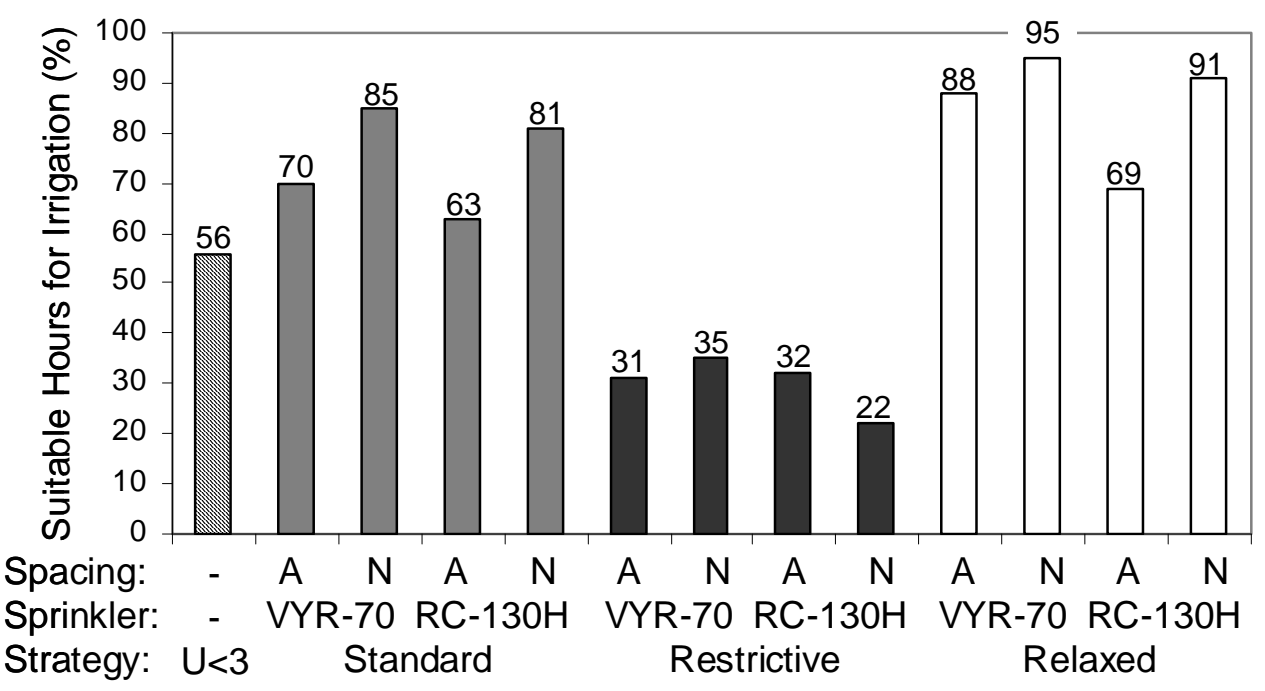

